\title{
European Fiscal Union: A Vision for the Long Run
}

\author{
Carlo Cottarelli ${ }^{a}$
}

JEL-Classification: H6

Keywords: debt, debt brake, fiscal rules, European Fiscal Union

First let me thank the Ministry of Finance of Switzerland for inviting me here to this important conference. The Swiss Debt Break rule has represented over the last ten years a model for fiscal rules in other countries. It has worked well because its design has reconciled the need for short-term flexibility with that of anchoring underlying medium- and longer-term fiscal policy trends.

My presentation today, as the title indicates, focuses on a topic that is of great importance for Switzerland as it affects the economic future of its most important trading and financial partner: the euro-area and its members.

As you know, in their report of June 26, 2012, the "four presidents" underscored that "The smooth functioning of the EMU requires ... a qualitative move towards a fiscal union." In mid-October an interim report including a road map on how to move towards a fiscal union was published and expectations are high regarding the publication of the final report this December.

The debate on the features of a euro area fiscal union has often focused on the minimum conditions necessary for such a union to be supportive of a full recovery of the viability of the euro project. This minimalist approach is reasonable, because political realities have to be taken into account. However, in defining these minimum conditions it is critical to keep in mind the long-run goals of a fiscal union, as short-term configurations should contribute to, or at least not impede, progress towards long-run objectives. My presentation today will lay out several technical considerations related to some desirable long-run features of a fiscal union in the euro area.

Director of Fiscal Affairs Department, IMF, Washington; ccottarelli@imf.org. 


\section{The Case for a Fiscal Union: Idiosyncratic Shocks and Idiosyncratic Policies}

The crisis and the shortcomings it revealed in the current policy coordination framework in the euro area provide a natural starting point to think about the optimal features of a fiscal union in Europe. Many observers have stressed the need for better risk-sharing tools that could help member countries hit by idiosyncratic shocks overcome their temporary difficulties. This focus on the problems that idiosyncratic shocks can create within a currency union is legitimate, and is consistent with a key criticism levied against the design of the euro area architecture: the insufficient consideration for the management of shocks that may hit only part of the union and that, therefore, cannot be addressed either through a single monetary policy nor through state fiscal policies, given the constraints imposed (at least in principle) on the fiscal position of member states. Among other things, the crisis showed that, with growing interconnectedness among member countries, the spillovers from country-specific shocks have gained the potential to reach systemic levels. Sovereign bank feedback loops have led to bad equilibria, where markets can price in default in a self-fulfilling way. In that context, ex ante risk sharing to smooth the impact of these shocks is of paramount importance.

However, alongside this, it is equally important to recognize that the problems that some euro-area member countries - and, as a consequence, the euro project - are currently facing is also due to shocks that were policy-induced. They reflected, in other words, idiosyncratic policies that exposed countries to the risk of market pressures, or added to or compounded exogenous idiosyncratic shocks. In many cases, this produced a difficult mix, with the relative importance of idiosyncratic policies and idiosyncratic shocks varying across countries.

Countries such as Ireland and Spain provide one example of idiosyncratic shocks, as they suffered from housing booms that may have been difficult to control through internal policies (although policies were far from perfect, at least with the benefit of hindsight, as, for example, increased public spending was financed by revenues that turned out to be temporary). Other countries (like Italy and Portugal) that had specialized in low-value added goods suffered from a globalization shock. One example of idiosyncratic policies - definitely not the only one was Greece, which was affected by a loss of confidence related to the weakness of its fiscal accounts and a loss of competitiveness. In 2007, at the outset of the global economic and financial crisis, its general government deficit amounted to 7 percent of GDP, well above the SGP ceiling. What is perhaps worse, it was 
largely underestimated - available statistics indicated a deficit below 3 percent of GDP - which caused a major confidence shock when the full extent of the imbalance came to the surface. The debt ratio was also largely underestimated, at 93 percent of GDP against an actual 107 percent.

Altogether, a fiscal union should be designed with the goal of both: (i) reducing the risks stemming from idiosyncratic shocks and, at the same time, (ii) reducing the potential damage that idiosyncratic policies can cause. Of course, idiosyncratic policies were made possible by the inadequacy of the euro area institutions that were meant to achieve policy coordination. A fiscal union should indeed address these policy coordination failures.

In light of the recent crisis in the euro area, and based on the experience of existing fiscal federations/currency areas, a fiscal union that meets the needs of the euro could be built on three pillars:

- Stronger constraints relating to member state deficits and debt, including public financial management processes, which would reduce the risk of idiosyncratic fiscal policy shocks;

- a larger central budget, as this would both provide the tools for risk sharing and contribute to reducing some key economic differences across countries;

- and increasing the harmonization of non fiscal policy, starting with the priority of setting up a banking union with an appropriate fiscal backstop to sever the sovereign-bank links that have slowed the resolution of the crisis.

Let me take up one by one these three components. However, one caveat is needed: the strength of fiscal integration will have to move pari passu with some form of increased political integration, and this may impose limits on what forms of fiscal union are feasible and how quickly Europe can move towards its ultimate objectives, whatever they may be. A discussion of possible increased forms of political integration, however, goes beyond the scope of this presentation.

\section{Stronger Constraints on the Fiscal Policies of Member Countries}

A common feature of all fiscal unions is the existence of strong constraints to the ability of member states to run large fiscal imbalances. The underlying reason for this is to prevent unsustainable fiscal behavior at the local level from exerting negative effects over the entire union. These constraints are either imposed by the center or are self imposed (as in the case of the United States and Switzerland). Large local imbalances are not common in fiscal unions. For example, in 
the U.S. none of the 50 states had an average deficit larger than 1 percent of its GDP over the 3 years prior to the crisis. Similarly, none of the Canadian provinces recorded average deficits greater than 2 percent of GDP during 2005-2010, with most provinces showing deficits of less than 1 percent of GDP.

The strengthening of the fiscal compact, the "six pack" and the forthcoming "two pack" are meant to strengthen the constraints on local fiscal policies. All this heads in the right direction. The fact that the constraints on member states are defined in structural, not headline, terms is particularly welcome: given the more limited labor mobility prevailing in the euro area, allowing the full operation of the automatic stabilizers at the state level is a useful feature of the enhanced fiscal governance rules. This said, implementation will be critical. Moreover, a key issue is whether this approach - based on rules, closer monitoring, and ex post sanctions - will be sufficient over the long run or whether the center should have ex ante veto rights on members' fiscal policies. Such veto power does not normally exist even in political unions. This does not necessarily imply that such an approach would be inappropriate in the euro area. But it will no doubt be a challenge for such a strong form of external intervention (outside the "conditionality" discussed below in case of external financial support) to become a political reality. Moreover, the strengthening of the European budget, also discussed below, would reduce the likelihood of state budgets becoming sources of fiscal instability, thus making less necessary the introduction of even stronger forms of central control over state budgets.

Enforcement of these fiscal constraints requires effective surveillance of fiscal developments at the member state level. This requires (i) common accounting standards across member states to ensure consistent application of state fiscal rules; (ii) frequent and timely reporting of fiscal data to enable pro-active enforcement of those rules; and (iii) effective audit arrangements to ensure the credibility of reported data. These preconditions are not always met even in some of the most advanced federal states. In Germany, for example, individual Länder are allowed to follow their own accounting standards. This has made it difficult for the Federal Government to produce fiscal statistics for the consolidated general government with anything less than a 12-month lag. In Spain, efforts by the central government to detect emerging fiscal problems and to require sub-national governments to take corrective action have been frustrated by long reporting lags. At the euro area level, the new Budget Frameworks Directive rightly emphasizes more regular and comprehensive publication of member state data. However, while the Directive calls for independent audit of the quality of government accounts, it does not prescribe the accounting standard to be used by the auditor in determining whether such accounts represent a true and fair 
view of the government's financial position. The reporting requirements could be made more stringent by asking member states to produce, possibly after a transition period, accounting information that complies with internationally recognized standards.

\section{A Larger Central Budget}

Fiscal unions differ in the magnitude of centralized fiscal policy functions, but, in all cases, the setting always provides for some form of risk sharing through cyclical transfers. What is clear is that the EU budget is in no condition to play such a role, being less than 1 percent of the region's GDP, and focused on agricultural subsidies and structural funds. In federal states the bulk of these transfers do not arise from discretionary decisions taken by the center, which could prove extremely controversial politically, nor from ad hoc transfer mechanisms, but rather from the centralization of certain spending policies that are particularly sensitive to cyclical developments, such as unemployment insurance. Another, and even larger, natural absorber of shocks arises from the fact that the revenues devoted to the central budget are also sensitive to cyclical developments. ${ }^{1}$

There are other mechanisms one can consider to deliver risk sharing, such as a rainy day fund that would accumulate contributions from all during good times and redistribute them to specific countries when they are hit by idiosyncratic shocks. In that case, no specific fiscal function would be transferred to the center. Both types of solutions have pros and cons. However, one advantage, over the longer run, of a larger central budget is that it reduces the risk of idiosyncratic fiscal policies at the state level, and so supports the first pillar discussed above. The larger is the share of the spending responsibilities that are centralized, the lower is the likelihood that large fiscal imbalances arise at the local level. This is because the opportunities to spend locally are reduced if some spending categories are transferred to the center.

Another advantage of a sizable central budget is that it would allow for a much better coordination of fiscal policy in response to common shocks, and of course - for a larger countercyclical response at the union level. Finally,

1 A separate issue is the extent to which the centralization of cyclical revenues or spending contributes to alleviating idiosyncratic shocks. As a first approximation, such a centralization reduces commensurately the magnitude of the state-level automatic stabilizers if it is achieved purely by transferring to the center some cyclical spending and revenues. It can, however, help if the local automatic stabilizers are not able to operate fully either because of local fiscal rules or because of financing constraints. 
centralizing some spending and revenue policies would contribute to fostering economic convergence across member states, as fiscal policies can importantly affect economic incentives and behaviors. For example, a single unemployment insurance policy would, under certain conditions, make labor markets more similar across member states. In other words, policy centralization can help reduce the existing differences in economic structures and exposure to shocks.

\section{The Synergic Role of Harmonizing Non-Fiscal Policies}

The third component of a well functioning fiscal union in the long run relates to the harmonization, centralization, or coordination of other (non-fiscal) policies. Idiosyncratic shocks also arise from non-fiscal policies. Think of the importance of labor market policies for maintaining competitiveness. Or, even more to the point, that of the implementation of a banking union, including common regulation, supervision, deposit insurance and resolution processes.

Harmonizing these policies is critical for the working of a monetary and fiscal union and can have synergic effects with the strengthening of a central budget. For example, it would be more difficult to centralize unemployment insurance in the presence of largely divergent labor market policies. In turn, the latter is critical for the centralization of some of those policies. The obvious example is the existence at the central level of a common backstop to support the activities of a banking union.

The importance of harmonizing banking policies has been recognized with the decisive move of the euro area towards the creation of a banking union. More recently the proposal included in the interim report of the EU Council president on strengthening the economic and monetary union underscores the importance of harmonizing structural policies through agreements between individual countries and the EU institutions on reforms to promote growth of output and employment, including perhaps with limited, temporary financial support.

\section{Debt Centralization and Firewalls}

Altogether, these three components seem to be the necessary ingredients for the design of a fiscal union.

How about the centralization of debt and the availability of firewall resources (including the role of the central bank as lender of last resort), which have been the theme of much heated debates over the last couple of years? Are they a necessary component of a fiscal union in the long run? 
In federal states, federal debt is usually issued only to finance federal deficits (apart from rare cases of federal bailouts of subnational entities, often accompanied by a loss of discretionary policy powers by the latter). It seems therefore unlikely that the centralization of debt issuance to finance local deficits will need to be a permanent feature of a fiscal union in the euro area. Such a feature would violate the principle that member states, not the center, should be financially responsible for their own actions. This does not preclude, however, debt centralizations undertaken, on a one off basis, to overcome the current crisis. Indeed, some of the proposals put forward recently do regard the partial centralization of debt as a temporary solution, albeit a long-lasting one (as in the case of the European Redemption Pact proposed by the German Council of Economic Advisors). This position is consistent with what is often observed in the early stages of the formation of a fiscal union, when, on a one off basis, the center has sometimes taken over local debt (e.g., after the American War of Independence, or in Brazil during the 1990s). Indeed, some centralization of existing debt may be useful to kick off the market for federal securities which would be eventually used for the financing of a larger central budget.

By the same token, one could argue that firewall provisions should be regarded as a temporary device to overcome the current crisis. There are, however, reasons why ESM-like structures could become permanent features of a euro area fiscal union. One reason is that the likelihood of idiosyncratic shocks leading to financing problems could be higher in an area where, because of language barriers or other factors, labor mobility will likely remain more limited than, say, in the United States. In the presence of relatively lower labor mobility, emergency/crisis financing from the center may become necessary. This said, one key principle must be preserved: that member countries should be responsible for their actions so that support from other members in the presence of a crisis does not come as a free good. Therefore, strict conditionality would be needed.

\section{Implications for the Immediate Future}

What are the implications of the above discussion for the measures that could be undertaken as minimum features of a fiscal union to be implemented in the short run?

- First, steps toward completing one of the three components of the above model are already being implemented: the tightening of state level budget constraints 
is an important component to reduce the likelihood of fiscal policy induced idiosyncratic shocks. But implementation will be key.

- Second, preference should be given to short run solutions that are consistent with the preferred long term architecture. If the latter includes a strengthening of the central budget, then such strengthening could start with the provision of resources to backstop the banking union, or to centralize policies involving risk-sharing mechanisms. Later, euro area infrastructure investment projects could move ahead of the centralization of other spending policies. To the extent that these were deficit financed, these activities could give rise to the issuance of (joint and several) euro area debt.

- The establishment of stronger processes to promote nonfiscal structural reforms, as proposed in the October 12 interim report by the European Council President, is a priority also for the short run, together with the establishment of a banking union.

- Finally, the resolution of the current crisis may involve the use of solutions that are not part of the long-run features of the euro area fiscal union. But those would have to be identified as such (which may make them politically more acceptable with respect to proposals that see them as permanent features of the system).

\section{Conclusions}

In conclusion, the crisis revealed that a monetary union can be put at risk when the economies of member countries remain so different, and when adequate processes for risk sharing are not available. Economic differences were exacerbated by coordination failures resulting in idiosyncratic fiscal (and non fiscal) policies (insufficient fiscal discipline and opacity of the fiscal accounts for both flows and stocks, unreformed labor markets and lack of productivity growth and competition). More Europe, not less Europe, is needed to reduce these idiosyncrasies and imbalances across countries. A wide range of risk exposure across countries is harmful to a monetary union. But, equally important, as these disparities are reduced, there is also a need for better sharing of the residual risk. 